
\title{
25 Research Sourere \\ Effects of inducible and constitutive expression vectors on heterologous expression of LEH mutants BE3 and BG5
}

Jie Yong

Hunan Agricultural University https://orcid.org/0000-0002-7428-1664

Binghuan Liu

Hunan Agricultural University

Kunlun Wang

Hunan Agricultural University

Hui Yang

Hunan Agricultural University

Yun Tian

Hunan Agricultural University

Haiyan Zhou ( $\nabla$ sws001@163.com )

Hunan Agricultural University https://orcid.org/0000-0002-7230-5669

Research

Keywords: Limonene epoxide hydrolase, Enantiomers, Non-induced expression, Heterologous expression

Posted Date: January 25th, 2021

DOI: https://doi.org/10.21203/rs.3.rs-152356/v1

License: (1) This work is licensed under a Creative Commons Attribution 4.0 International License.

Read Full License 


\section{Abstract \\ Background}

Limonene epoxide hydrolase (LEH) is a class of enzymes in Epoxide hydrolases (EHs) that can form chiral products only by one step catalysis. High purity $S$ or $R$ chiral intermediates play an important role in the application of biomedical industry, and can be used to synthesize various drugs such as ibuprofen, linezoline, cilastatin, etc. Therefore, it has application value to find the expression system which can realize the stable and efficient conversion of LEH to produce high purity $S$ and $R$ chiral products.

\section{Results}

We explored the constitutive expression system of LEH for the first time, and tried to realize the expression of LEH in B.subtilis WB800. Firstly, the LEH mutant on the original inducible vector pBAD-MycHisA was obtained and connected to the constitutive vector pHY-p43 containing strong promoter $\mathrm{p} 43$. $E$. coli TOP10 and B.subtilis WB800 were used as the host bacteria to realize the non induced and secretory expression of LEH.

\section{Conclusions}

The results showed that the non induced expression of LEH could be achieved successfully by using the constitutive promoter vector pHY-p43, and the substrate affinity and enzyme catalytic efficiency of the mutants have increased. The catalytic decomposition of the substrate and the formation of chiral products by LEH were determined by GC-MS, which also had stable enzyme activity in the system. This study laid a foundation for large-scale fermentation of LEH and catalytic production of chiral products.

\section{Background}

EHs play an important role in microorganisms, plants, insects and mammals. The three main function of EHs are detoxification, catabolism, and regulation of signaling molecules ${ }^{[1]}$. Which is different from other EHs enzyme reactions requiring two steps, and the LEH from Rhodococcus erythropolis DCL $14^{[2]}$ only one step complete catalytic reaction. So this reaction doesn't require any other coenzyme to participate, the catalytic mechanism is that the active center is composed of Asp-Arg-Asp triad ${ }^{[3]}$, which involves epoxide protonation by Asp101, nucleophilic attack by water, and abstraction of a proton the water by Asp132. Tyr53, Asn55 and Asp132 position water molecules in a favorable position for epoxide attack and activated water molecules by hydrogen bonds. Asp132 abstracts a proton from the water molecules. Meanwhile, Asp101 supplies of protons to the epoxide ring of the substrate to activate the epoxide ring, promoting nucleophilic attack on epoxide carbon. Arg99 locates the carboxyl groups of Asp101 and Asp132 as a proton shuttle assisted proton balance and charge stabilization (Fig. 1). ${ }^{[3,4]}$. 
Epoxides as important substrates for EHs also play an important role in chiral pharmaceuticals synthesis and rubber product development ${ }^{[5]}$. Among them, the $(R)$ - or $(S)$-enantiomers of the absolute configuration produced by chiral epoxides usually have different functions and effects, such as anti-inflammatory antalgica drugs ibuprofen and $\beta$-receptor blocker propranolol ,compared with $(S)$-ibuprofend, $(R)$ ibuprofen can achieve significant effect at lower concentration ${ }^{[6]}$; $(S)$-propranolol has a $\beta$-receptor blocker effect about 100 times stronger than $(R)$-propranolol, and is an enantiomer that plays a major role in the treatment of angina pectoris ${ }^{[7]}$. The experiment will be based on two of the mutants that have significant enantioselectivity, and explore the influence of different expression systems on LEH expression in the form of organic phase catalysis in accordance with the requirements of environmental protection and production application, in order to obtain high purity chiral enantiomers through stable and efficient enzyme catalysis.

Additionally Escherichia.coli (E.coli) is a commonly used host strain of prokaryotic expression systems, which has significant advantages ${ }^{[8]}$, but it also has disadvantages that are difficult to overcome, such as the presence of the target protein often in the form of inclusion bodies leads to difficulty in product purification and low product biological activity ${ }^{[9]-[10]}$. For the absence of Bacillus subtilis (B. subtilis) outer membrane, $B$. subtilis can simplify the protein secretion pathway and secrete high-level extracellular protein. As early as 2007 , due to the unique protein secretion ability of $B$. subtilis, about $60 \%$ of the enzymes on the market were produced by $B$. subtilis ${ }^{[11]}$. Therefore, E. coli and $B$. subtilis as a heterogenic expression host has considerable research and application value.

\section{Materials And Methods}

\section{Strains, plasmids and chemicals}

The plasmid pHY-P43 was purchased from YouBio (Changsha, China); The limonene epoxide hydrolase (LEH) mutants library were constructed by professor Dick B. Janssen group of University of Groningen ${ }^{[12]}$; The clone strain competent cells E.coli Top10 was purchased from Tiangen (Beijing, China); The expression strain B. subtilis WB800 was presented by professor Wei xuetuan of Huazhong Agricultural University; The substrates cyclohexene oxide ( $\mathrm{CHO}$ ) was purchased from $\mathrm{TCl}$ (Tokyo, Japan); The media used in the experiment were Luria-Bertani (LB) medium and Terrific Broth (TB) medium.

\section{Construction of recombinant heterologous expression vector}

According to the sequencing results of the pBAD-LEH mutant, a pair of primers were designed to amplification the LEH mutants BE3 and BG5, restriction enzyme BamHI and EcoR I was selected as the restriction site at the multipe cloning site of the pHY-p43, Forward primer(BamHI)ख5'CGGGATCCCGTTGGGCTAACAGGAGGAATTAC-3', Reverse primer (ECoRI): 5'-CGGAATT

CCGCAAGCTGGAGACCGTTTAAACT-3', specific amplification of the target gene from BE3 and BG5, the full length of the segment is $570 \mathrm{bp}, \mathrm{PCR}$ system: $94^{\circ} \mathrm{C}, 5 \mathrm{~min} ; 94^{\circ} \mathrm{C}, 30 \mathrm{~s}, 65^{\circ} \mathrm{C}, 30 \mathrm{~s}, 72^{\circ} \mathrm{C}, 30 \mathrm{~s}, 30$ 
cycles; $72^{\circ} \mathrm{C}, 10 \mathrm{~min}$, target gene purified and digested by $\mathrm{BamHI}$ and $E c o R \mathrm{I}$ at $37^{\circ} \mathrm{C}$ for $4 \mathrm{~h}$, the expression vector $\mathrm{pHY}-\mathrm{p} 43$ also digested by $\mathrm{BamHI}$ and $E c o R \mathrm{I}$, then ligated into the vector pHY-p43.The recombinant plasmids be transformed into E.coli Top10 and the successfully sequenced recombinant was extracted extracted and transferred into B.subtilis WB800 competent cell by electrical transformation $^{[13]}$, get the recombinant pHY-p43-BE3 map (Fig. 2A) and pHY-p43-BG5 map (Fig. 2B)

\section{Protein structure homology simulation and molecular docking}

The protein crystal structure of the limonene-1,2-epoxide hydrolase $\mathbb{Z L E H} \Downarrow$ subunit of Rhodococcus erythropolis was obtained from the PDB database (PDB ID: 1NWW, 5CF2). The protein monomer sequence was obtained by bGI gene sequencing. The structure models of the variants BE3 and BG5 were constructed by homology modeling and downloaded from SWISSMODEL Workspace (http://swiss model .expasy.org/() ${ }^{[14]-[15]}$. Molecular docking of the LEH mutant with the substrate cyclohexene oxide was completed by Autodock4.2.6. All water molecules were removed, nonpolar hydrogen atoms added and protein displayed by Pymol (http://www.pymol.org).

\section{Screening for high activity variants}

All the plasmids pBAD-LEH were transformed into E. coli Top10 and cultured in TB medium. When the culture reached $\mathrm{OD}_{600}$ of $0.6,0.02 \% \mathrm{~L}$-arabinose was added for $\mathrm{LEH}$ production inducer and the culture was incubated for a further $16 \mathrm{~h}$ at $30^{\circ} \mathrm{C}$. pHY-p43-LEH culture by LB medium, and after transformed into E. coli Top10, the culture was incubated for a further over $12 \mathrm{~h}$ at $37^{\circ} \mathrm{C}$. Cells were harvested by centrifugation ( $10 \mathrm{~min}, 6,000 \times \mathrm{g}, 4^{\circ} \mathrm{C}$ ), and each $100 \mathrm{mg}$ of cells was resuspended in $1 \mathrm{~mL}$ buffer (50 mM Hepes, $\mathrm{pH} 8.0$ ), lysed by sonication (total time $20 \mathrm{~min}$, cycles of $5 \mathrm{~s}$ on $10 \mathrm{~s}$ off, $60 \mathrm{Watt}, 4^{\circ} \mathrm{C}$ ). The cell debris was removed by centrifugation $\left(30 \mathrm{~min}, 6,000 \times \mathrm{g}, 4^{\circ} \mathrm{C}\right)$ and the supernatant was collected into the eppendorf tubes.

For $B$. subtilis WB800, the culture was incubated at $37^{\circ} \mathrm{C}$ for a further $20 \mathrm{~h}$ after being transformed and the supernatant was collected. Proteins were purified by the Protein purification kit (His-tagged Protein Purification Kit, China); The cell-free extract was loaded on the column and washed by the loading buffer (followed by the kit's instruction) to remove unbound contaminants and the eluting solution between the $5 \mathrm{ml}$ to $10 \mathrm{ml}$ was collected. The proteins were desalted and concentrated by the ultrafiltration centrifuge tubes (Milipore). The protein concentration was determined using the Bradford ${ }^{[16]}$ procedure and purity was analyzed using $12 \%$ SDS-PAGE.

\section{Enzyme assay and GC analytics}

After desalination and concentration, LEH from E. coli TOP 10 was obtained to detect enzyme activity and kinetic parameters by gas chromatograph-mass spectrometry (GCMS-QP2020囚Japan). Substrate solution was prepared with $1 \mathrm{M}$ substrate in acetonitrile to make the stock solution, then diluted 20-fold in $50 \mathrm{mM}$ potassium phosphate buffer (final pH 7.0 and final concentration $50 \mathrm{mM}$ ). In a $4 \mathrm{~mL}$ glass vial with cap, $980 \mu \mathrm{L}$ substrate solution is mixed $20 \mu \mathrm{L}$ enzyme stock solution (LEH $(1 \sim 5 \mathrm{mg} / \mathrm{mL})$ in $10 \mathrm{mM}$ 
HEPES buffer ( $\mathrm{pH} 7.5))$ and incubate at $30^{\circ} \mathrm{C}$. After 90 min incubation, in duplo, take a sample of $400 \mu \mathrm{L}$ and add it to $400 \mu$ l ethylacetate containing $1 \mathrm{mM}$ IS (ethylacetate with $1 \mathrm{mM}$ hexadecane as internal standard) in a $2 \mathrm{~mL}$ Eppendorf tube. Add $120 \mu \mathrm{l}$ of $5 \mathrm{M} \mathrm{NaCl}$ in water, Mix well, vortex $20 \mathrm{~s}$, centrifuge (8000 rpm, $2 \mathrm{~min}$ ) and using a Pasteur pipette place the supernatant in a new eppendorf vial. Repeat the extraction with another $400 \mu \mathrm{l}$ of ethylacetate containing IS. Combine the two ethylacetate extracts and dry with solid $\mathrm{MgSO}_{4} .150 \mu$ of the water-free supernatant is analyzed by chiral gas chromatography. Injector (split) and detector (FID) at $200^{\circ} \mathrm{C}$, sample temperature $200^{\circ} \mathrm{C}$, carrier is nitrogen at a flow rate of $1 \mathrm{~mL} / \mathrm{min}$. For cyclohexene oxide :temperature starts from $40^{\circ} \mathrm{C}$, hold for 1 minute, increase to $150^{\circ} \mathrm{C}$ at $10^{\circ} \mathrm{C} / \mathrm{min}$; hold $6 \mathrm{~min}$ at $150^{\circ} \mathrm{C}$; Measure peak area's and using the internal standard peak area's and a calibration curve, calculate concentrations. One unit $(U)$ is the amount of enzyme that produces $1 \mu \mathrm{mol}$ of product per min.

\section{Determination of the Extracellular expression LEH mutants enzyme properties}

The optimum temperature of LEH from E.coli TOP 10 was determined using $50 \mathrm{mM} \mathrm{HEPE} \mathrm{buffer}(\mathrm{pH} 7.5)$ with temperature ranging from 50 to $85^{\circ} \mathrm{C}$. The optimum $\mathrm{pH}$ was measured by assaying the enzyme activity at various $\mathrm{pH}$ values $(0.05 \mathrm{M} \mathrm{KP}$ (potassium phosphat) buffer, $\mathrm{pH} 5.8-8.0)$ at $30^{\circ} \mathrm{C}$. Kinetic parameters of the LEH variants were determined in $\mathrm{KP}$ buffer $(0.05 \mathrm{M}, \mathrm{pH} 7)$ at $30^{\circ} \mathrm{C}$ with varied concentration of the substrate cyclohexene oxide (with concentration range from $1 \mathrm{mM}$ to $70 \mathrm{mM}$ ). Kinetic parameters $V_{\max }$ value, $k_{\text {cat }}$ value and $K_{\mathrm{m}}$ value were obtained with the help of software Originpro 2021 by plotting enzymatic activity versus substrate concentrations and fitting them using the Michaelis-Menten equation.

\section{Results And Discussion}

\section{LEH characteristics and screeing mutant library}

Based on the mutant library constructed with the vector pBAD/Myc-His $\mathrm{A}^{[12]}$, all mutants were transformed, cultured and purified to verify the enantioselectivity (Table 1). Since mutant BE3 had significant (S) - enantioselectivity and mutant BG5 had (R) - enantioselectivity in our experiment, they were selected for the subsequent test.

\section{Table 1 Screening and verification of LEH mutant library}




\begin{tabular}{|c|c|c|c|}
\hline Mutants & Mutation site & $e e(\%)$ & $\mathrm{C}(\%)$ \\
\hline AG9 & T76K/T85V/N92K/Y96F/E124D/I5C/E84C/G89C/S91C & $10.59 \pm 0.29(R, R)$ & 99.15 \\
\hline \multirow[t]{2}{*}{$\mathrm{AH} 6$} & T76K/T85V/N92K/Y96F/E124D/ & $16.68 \pm 0.25(R, R)$ & 99.99 \\
\hline & I5C/A17C/E84C/N92C & & \\
\hline BE3 & M32L/L74F/I80F/L103I/I116V/F139L & $86.44 \pm 0.78(S, S)$ & 22.06 \\
\hline BE5 & $\mathrm{M} 78 \mathrm{~L} / 180 \mathrm{~F} / \mathrm{I116V} / \mathrm{F} 139 \mathrm{~W}$ & $14.05 \pm 0.67(S, S)$ & 91.25 \\
\hline BE6 & M32A/L35W/M78I/I80A/V83A/I116V & $34.86 \pm 6.49(S, S)$ & 10.99 \\
\hline BE7 & M32L/I80W/L103I/I116V/F139W & $6.67 \pm 5.77(R, R)$ & 17.34 \\
\hline BE9 & M32L/L35M/L74I/M78I/I80F/V83I/ L103V/I116V/F139L & $83.30 \pm 8.53(S, S)$ & 8.57 \\
\hline BF2 & M32L/M78L/I80F/I116V/F139W & $0.61(S, S)$ & 61.17 \\
\hline BF3 & M78W/F139W & $41.56 \pm 1.27(R, R)$ & 32.15 \\
\hline BF4 & M32A/L35M/M78L/I80W/L103V/ I116V/F139W & $1.79 \pm 0.21(R, R)$ & 19.74 \\
\hline BF5 & M32L/L35M/L74I/M78V/I80F/V83G/ L103V/F139L & $49.66 \pm 14.27(R, R)$ & 0.29 \\
\hline BF6 & $\mathrm{L} 74 \mathrm{I} / \mathrm{I80F} / \mathrm{I116V/F139W}$ & $5.87 \pm 2.71(R, R)$ & 99.04 \\
\hline BF7 & M32L/L35M/M78L/I80F/L103I/I116V/F139L & $60.11 \pm 2.11(S, S)$ & 79.84 \\
\hline BF8 & M32L/L35M/M78L/I80W/V83I/ L103I/I116V/F139W & $11.28(S, S)$ & 10.62 \\
\hline BF9 & M32L/L35W/L103I/I116V/F139W & $9.31 \pm 0.46(S, S)$ & 64.32 \\
\hline BG1 & M32L/L74F/M78A/I80F/L103I/ I116V/F139L & $73.63 \pm 2.27(S, S)$ & 64.43 \\
\hline BG2 & M32L/M78I/I80W/L103I/I116V/F139L & $60.58 \pm 4.97(S, S)$ & 13.24 \\
\hline BG3 & M32L/L35W/M78I/I80A/L103I/I116V/F139L & $25.51 \pm 5.89(R, R)$ & 37.48 \\
\hline BG5 & M32L/L74I/I80V/L103F/F139L & $79.41 \pm 0.92(R, R)$ & 62.37 \\
\hline BG6 & M32L/L74I/I80V/L103F/F139W & $70.89 \pm 1.58(R, R)$ & 73.90 \\
\hline BG7 & M32L/L74I/L103F/F139W & $60.40 \pm 1.20(R, R)$ & 58.34 \\
\hline BG8 & M32L/M78G/L103F/F139M & $30.35 \pm 0.28(R, R)$ & 84.36 \\
\hline BG9 & M32L/M78G/L103F/I116V/F139L & $54.63 \pm 1.80(S, S)$ & 97.61 \\
\hline $\mathrm{BH} 2$ & M32A/M78G/L103F/F139L & $18.46 \pm 0.91(R, R)$ & 97.85 \\
\hline
\end{tabular}

Note: for the substrate $\mathrm{CHO}$; $\%$ : conversion rate

LEH catalyzes the hydrolysis of cyclohexane oxide to vicinal diol cyclohexane-1,2-diol (Fig. 3). The substrate $\mathrm{CHO}$ was molecular docked with BE3 and BG5. The docking grids of BE3 was set to $46 \times 54 \times 64$ 
$\AA$, and the docking grids of BG5 was set to $54 \times 52 \times 40 \AA$. For the docking results, $\mathrm{CHO}$ was located on the surface of the protein to the catalyst. BG5 has a larger cavity than BE3, which can reduce steric hindrance and is more conducive for $\mathrm{CHO}$ to enter the ligand channel (Fig.4).

\section{Construction of pHY-p43-LEH expression vector}

Mutants BE3 and BG5 genes were amplified from plasmid pBAD-LEH mutants library. The double enzyme digestion products of target fragments $\mathrm{BE} 3, \mathrm{BG} 5$ and vector $\mathrm{pHY}-\mathrm{p} 43$ were successfully recovered (Fig. $5 A)$. After connection and transformation, some single colony was selected by bacteria liquid PCR, then the transformed plasmids were extracted for plasmid PCR and double enzyme digestion (Fig. 5B-C).

\section{LEH heterologous expression in E. coli Top10 and B. subtilis WB800}

Plasmids pHY-p43-BE3 and pHY-p43-BG5 transformed into E. coli TOP10 were cultured over $12 \mathrm{~h}$, and proteins were purified by $6 \times$ His affinity chromatography. SDS-PAGE detection showed that pHY-p43 /TOP10 system expressed LEH successfully (Fig. 6A), and the sequencing results also showed that the target fragments were correctly connected.

Meanwhile, pHY-p43-BE3 and pHY-p43-BG5 were transformed into $B$. subtilis WB800 by electrotransformation. From the SDS-PAGE results, the expression in B. subtilis WB800 was lower than the expression in E. coli, therefore the latter strain was considered for the optimized system (Fig. 6B).

\section{Enzymatic characteristics of mutants BE3 and BG5 in different systems}

For the protein expression of pBAD/Myc-HisA-LEH system needs to add a certain concentration of inducer and control the corresponding induction temperature and time, also the culture time is more than $20 \mathrm{~h}$. In order to make an efficient and economic procedure, the expression system of LEH was considered to be optimized. The constitutive vector pHY-p43-LEH containing strong promoter $\mathrm{p} 43$ was our selection for promoting the expression,pHY-p43 system did not need inducer, and the amount of protein needed in the experiment could be obtained by conventional temperature $37^{\circ} \mathrm{C}$ and $\mathrm{LB}$ medium for cultured more than $12 \mathrm{~h}$.

In our experiment, LEH mutants were designed to catalyze substrate cyclohexene oxide (CHO). During the gas chromatography, retention times of cycloheptene oxide ca. 9.3min; acetonitrile ca. $8.8 \mathrm{~min}$; $(\mathrm{S}, \mathrm{S})$ cycloheptane diol ca. 13.7 min; (R,R)-cycloheptane diol ca. $14.0 \mathrm{~min}$; IS ca. $16.3 \mathrm{~min}$. Measure peak area's and the internal standard peak area's and a calibration curve, calculate concentrations (Table 2).

\section{Table 2 The substrate conversion and enantiomeric excess of mutants BE3 and BG5}




\begin{tabular}{|lll|}
\hline Mutant & CHO conversion (\%) & CHO ee(\%) \\
\hline pBAD-BE3 & 46.212 & -56.987 \\
\hline pBAD-BG5 & 33.477 & 40.886 \\
\hline pHY-P43-BE3 & 37.71 & -71.57 \\
\hline pHY-P43-BG5 & 39.93 & 69.55 \\
\hline
\end{tabular}

The mutants under the expression system were purified from E.coli TOP10, and the LEH expressed by different expression systems was determined to be affected by $\mathrm{pH}$, temperature and reaction time In the experiment, the $1 \mathrm{M}$ substrate stock solution was diluted with $50 \mathrm{mM}$ potassium phosphate buffer to 50 $\mathrm{mM}$, and $990 \mu \mathrm{L}$ substrate dilution and $10 \mu \mathrm{L} \mathrm{LEH}$ purified enzyme solution were incubated in a $5 \mathrm{~mL}$ glass bottle at $30^{\circ} \mathrm{C}$ for $90 \mathrm{~min}$. First, the optimal reaction temperature was determined, and the temperature was set at 30 to $85^{\circ} \mathrm{C}$. It was found that the same mutant had the same optimal temperature in different expression systems The optimal reaction temperatures for pBAD-BE3 and pHY-p43-BE3 are both at $65^{\circ} \mathrm{C}$, and the optimal reaction temperatures for pBAD-BG5 and pHY-p43-BG5 are both at $55^{\circ} \mathrm{C}$ (Fig. 7). Then the optimal $\mathrm{pH}$ was determined and configure the substrate diluted potassium phosphate buffer at 5.8, 6.2, 6.6, 7, 7.4, 7.8, 8. For pHY-p43-BE3 and pBAD-BG5, the catalysis was at the highest level at pH 6.2, and while the optimal pH of pBAD-BE3 is 5.8, pHY-P43-BG5 is 7.4 (Fig. 8).

Finally, the change of the different reaction time of each mutant was determined, and it basically belonged to a steady ascending state, and there were no significant changes (Fig. 9). Therefore, the reaction time of the subsequent experiment kept for $90 \mathrm{~min}$. The enzyme-catalyzed reaction was carried out under the above-mentioned single-factor optimal conditions, and it was found that the substrate conversion rate was significantly increased, and the conversion rate of pBAD-BE3 on $\mathrm{CHO}$ reached $100 \%$, but after the conversion rate increased, the ee value decreased (Fig. 10). It was speculated that the optimal temperature and $\mathrm{pH}$ of single factor had certain influence on the conformation of $\mathrm{LEH}$, and the formation of chiral products was also affected by the increase of catalytic efficiency.

\section{Kinetic analysis of LEH mutants expressed in E. coli Top10}

The kinetic parameters of mutant BE3 and BG5 were determined using different concentrations of substrate $\mathrm{CHO}$ from $1 \mathrm{mM}$ to $70 \mathrm{mM}$, and the reaction system was $990 \mu \mathrm{L}$ substrate dilution plus $10 \mu \mathrm{L}$ LEH solution in $5 \mathrm{~mL}$ incubater at $30^{\circ} \mathrm{C}$ for $90 \mathrm{~min}$, in which the substrate concentration was unique variable. The $K_{\mathrm{m}}$ value and $V_{\max }$ value are calculated by the Michaelis-Menten equation in the software Originpro 2021. From the table 3 , that the mutants of the p43 system have stronger substrate affinity and better catalytic efficiency than the pBAD system. Therefore, the p43 system was selected as the optimized plasmid expression system.

\section{Table 3 The kinetic parameters of mutants BE3 and BG5}




\begin{tabular}{|c|c|c|c|c|c|}
\hline Mutant & $\begin{array}{l}\text { Enzyme } \\
\text { concentration }(\mu \mathrm{mol} / \mathrm{L})\end{array}$ & $K_{m}(\mathrm{mM})$ & $\begin{array}{l}\text { Vmax } \\
\text { (umol/min·mg) }\end{array}$ & $K_{c a t}\left(\mathrm{~s}^{-1}\right)$ & $\begin{array}{l}K_{\text {cat }} K_{m} \\
\left(\mathrm{mM}^{-1} \mathrm{~s}^{-1}\right)\end{array}$ \\
\hline $\begin{array}{l}\text { pBAD- } \\
\text { BE3 }\end{array}$ & 3.557 & $\begin{array}{l}20.425 \pm \\
5.870\end{array}$ & 19.149 & 0.822 & 0.040 \\
\hline $\begin{array}{l}\text { pBAD- } \\
\text { BG5 }\end{array}$ & 2.548 & $\begin{array}{l}10.930 \pm \\
0.403\end{array}$ & 5.212 & 0.313 & 0.029 \\
\hline P43-BE3 & 1.962 & $9.797 \pm 1.640$ & 5.670 & 0.546 & 0.056 \\
\hline P43-BG5 & 1.188 & $9.08 \pm 4.11$ & 4.735 & 0.369 & 0.045 \\
\hline
\end{tabular}

Note: for the subatrate cyclohexane oxide

\section{Conclusions}

In summary, mutants BE3 and BG5 can catalyze the production of chiral enantiomeric products with distinct $S$ and $R$ configurations of the substrate $\mathrm{CHO}$. The change of expression system did not affect the enzymatic properties of LEH, but the mutants expressed in pHY-P43 expression system had higher substrate affinity and enzyme catalytic efficiency than PBAD/Myc-HisA, a the constitutive expression system significantly shortened the culture time and simplified the experimental procedures without affecting the protein expression level. Moreover, in the p43 constitutive expression system, the substrate affinity and enzyme catalytic efficiency of the mutants have increased. Combined with the enzymatic properties of mutants, $\mathrm{p} 43-\mathrm{BE} 3$ will give the highest catalysis at $\mathrm{pH} 6.2$ and $65^{\circ} \mathrm{C}$, and otherwise p43-BG5 will be at $\mathrm{pH} 7.4$ and $55^{\circ} \mathrm{C}$.

\section{Declarations}

\section{Acknowledgments}

The authors gratefully acknowledge the professor Dick B. Janssen and wijma (University of Groningen, Netherlands) for providing LEH mutants. Also acknowledge the professor Wei xuetuan (Huazhong Agricultural University, China) for providing strain B. subtilis WB800.

\section{Authors' contributions}

Jie Yong was responsible for the conception of the experimental framework, the construction and detection of protein expression vector and the writing of the paper. Binghuan Liu screened mutants. Kunlun Wang assisted in carrying out the experiment. Hui Yang guided bioinformatics related content such as homology modeling. Professor Yun Tian provides an experimental platform. Professor Haiyan Zhou is responsible for monitoring the progress of the experiment, guiding the article in detail and providing financial support for the experiment. 
Funding

This work was supported by Key Scientific Research Project of the Education Department of Hunan Province.19A226

Availability of data and materials

All data generated or analyzed during this study are included in this published article.

Ethics approval and consent to participate

Not applicable.

Consent for publication

Not applicable.

Competing interests

The authors declare that they have no competing interests.

\section{References}

1. Morisseau C, Hammock BD: Epoxide hydrolases: mechanisms, inhibitor designs, and biological roles.Annu Rev Pharmacol Toxicol 2005, 45:311-333.

2. Barbirato F, Verdoes JC, de Bont JAM, van der Werf MJ: The Rhodococcus erythropolis DCL14 limonene-1,2-epoxide hydrolase gene encodes an enzyme belonging to a novel class of epoxide hydrolases.FEBS letters 1998, 438:293-296.

3. Arand M, Hallberg BM, Zou J, Bergfors T, Oesch F, van der Werf MJ, de Bont JAM, Jones TA, Mowbray SL: Structure of Rhodococcus erythropolis limonene-1,2-epoxide hydrolase reveals a novel active site. The EMBO Journal 2003, 22:2583-2592.

4. Hopmann KH, Hallberg BM, Himo F: Catalytic Mechanism of Limonene Epoxide Hydrolase, a Theoretical Study.Journal of the American Chemical Society 2005, 127:14339-14347.

5. Saini P, Sareen D: An Overview on the Enhancement of Enantioselectivity and Stability of Microbial Epoxide Hydrolases.Mol Biotechnol 2017, 59:98-116.

6. Calcaterra A, D'Acquarica I: The market of chiral drugs: Chiral switches versus de novo enantiomerically pure compounds.J Pharm Biomed Anal 2018, 147:323-340.

7. Barrett A M, A. CV: The biological properties of the optical isomers of propranolol and their effects on cardiac arrhythmias.British Journal of Pharmacology 1968, 34:43-55.

8. Kaur J, Kumar A: Strategies for optimization of heterologous protein expression in E. coli: Roadblocks and reinforcements.Int J Biol Macromol 2018, 106:803-822. 
9. Fahnert B, Lilie H, Neubauer P: Inclusion bodies: formation and utilisation.Adv Biochem Eng Biotechnol 2004, 89:93-142.

10. Vallejo LF, Rinas U: Strategies for the recovery of active proteins through refolding of bacterial inclusion body proteins.Microb Cell Fact 2004, 3:11.

11. Fu LL, Xu ZR, Li WF, Bing J, Lu SP, Hu CX: Protein secretion pathways in Bacillus subtilis: implication for optimization of heterologous protein secretion.Biotechnol Adv 2007, 25:1-12.

12. Wijma HJ, Floor RJ, Bjelic S, Marrink SJ, Baker D, Janssen DB: Enantioselective enzymes by computational design and in silico screening.Angew Chem Int Ed Engl 2015, 54:3726-3730.

13. Lu YP, Zhang C, Lv FX, Bie XM, Lu ZX: Study on the electro-transformation conditions of improving transformation efficiency for Bacillus subtilis.Lett App/ Microbio/ 2012, 55:9-14.

14. Biasini M, Bienert S, Waterhouse A, Arnold K, Studer G, Schmidt T, Kiefer F, Gallo Cassarino T, Bertoni M, Bordoli L, Schwede T: SWISS-MODEL: modelling protein tertiary and quaternary structure using evolutionary information.Nucleic Acids Res 2014, 42:W252-258.

15. Simard JR, Getlik M, Grütter C, Pawar V, Wulfert S, Rabiller M, Rauh D: Development of a fluorescenttagged kinase assay system for the detection and characterization of allosteric kinase inhibitors. $J$ Am Chem Soc 2009, 131:13286-13296.

16. Bradford MM: A rapid and sensitive method for the quantitation of microgram quantities of protein utilizing the principle of protein-dye binding.Anal Biochem 1976, 72:248-254.

\section{Figures}




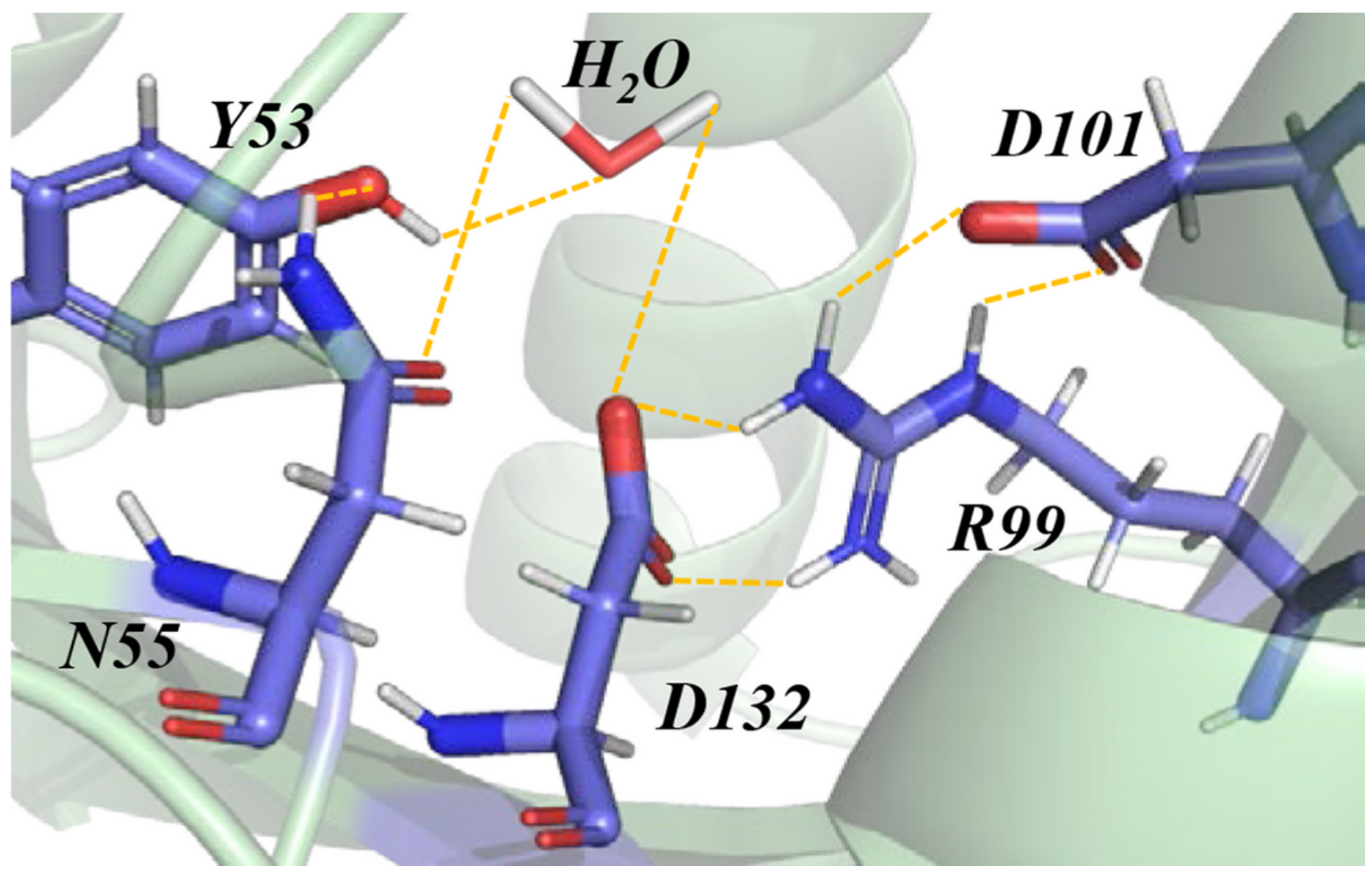

Figure 1

The catalytic mechanism of LEH 

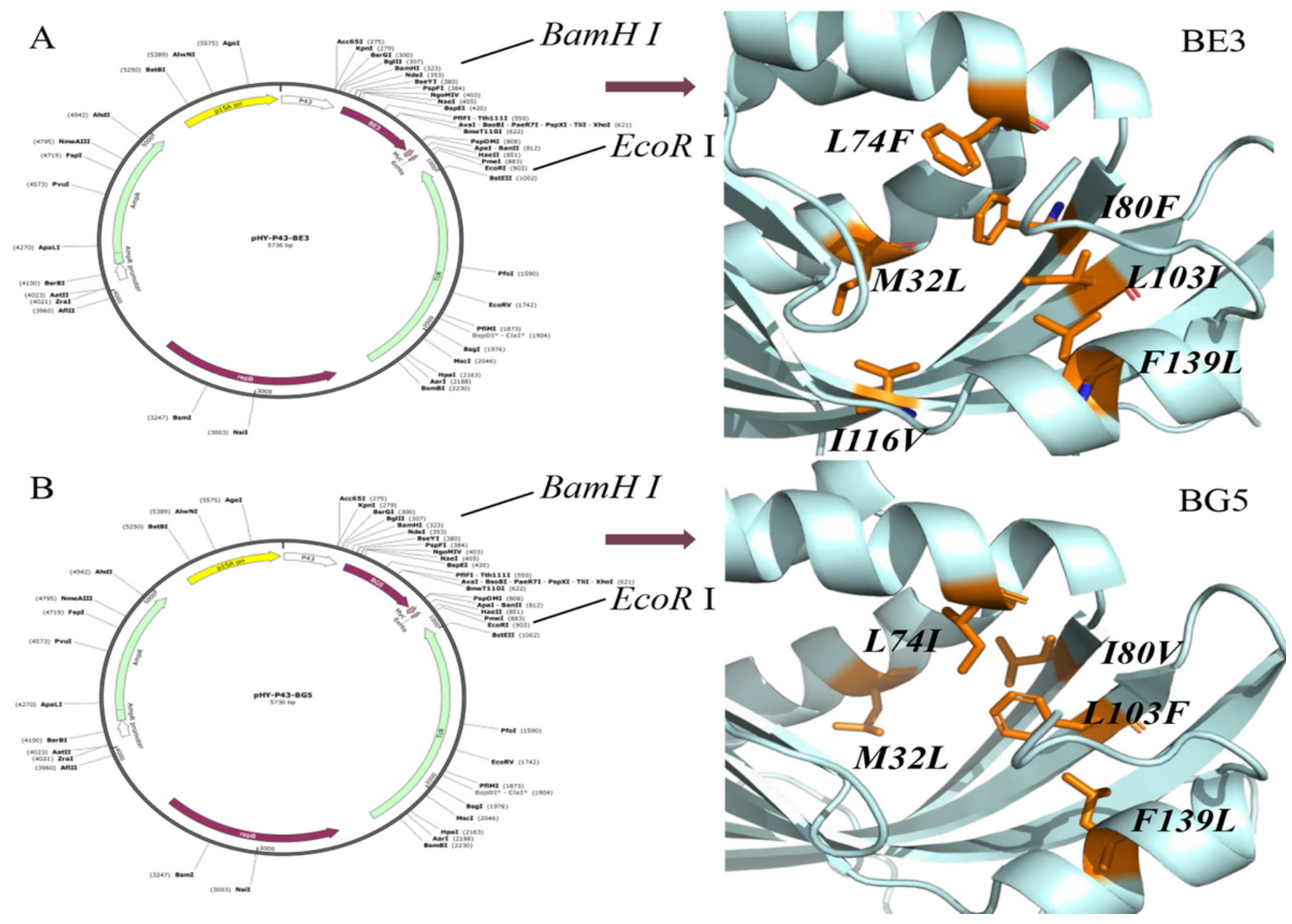

Figure 2

The pHY-p43-LEH map and structure models of LEH mutants BE3 and BG5
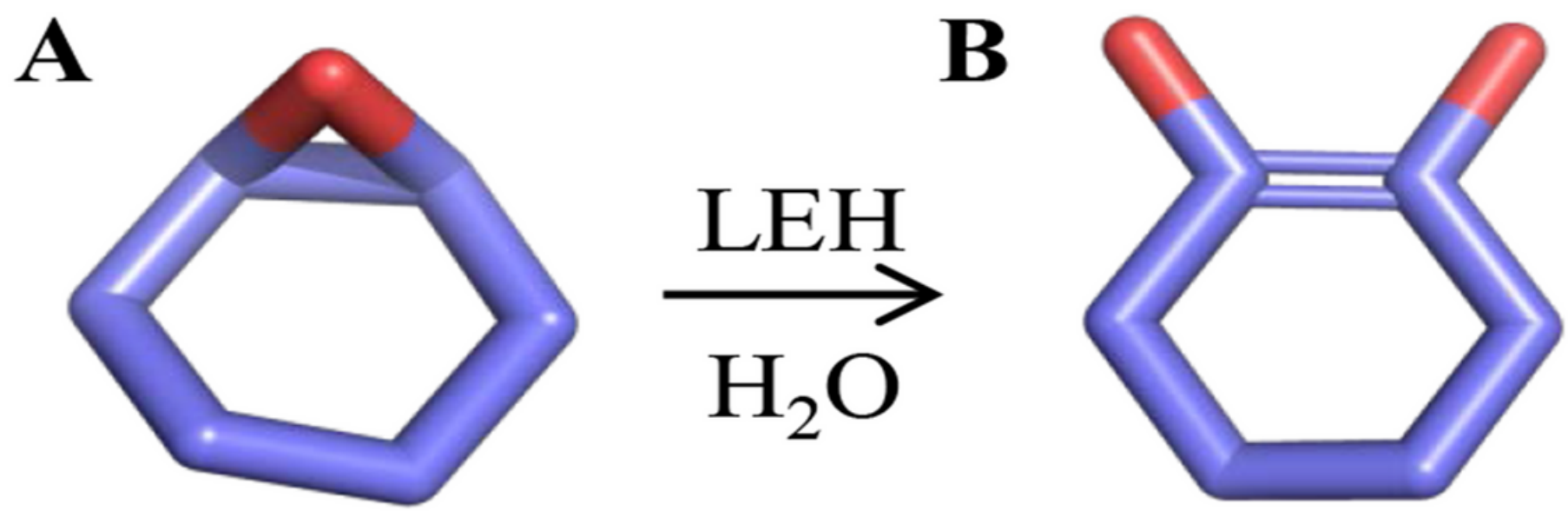

Figure 3

The catalytic of $\mathrm{CHO}$ by LEH. A: Cyclohexane oxide; B: Cyclohexane-1,2-diol 

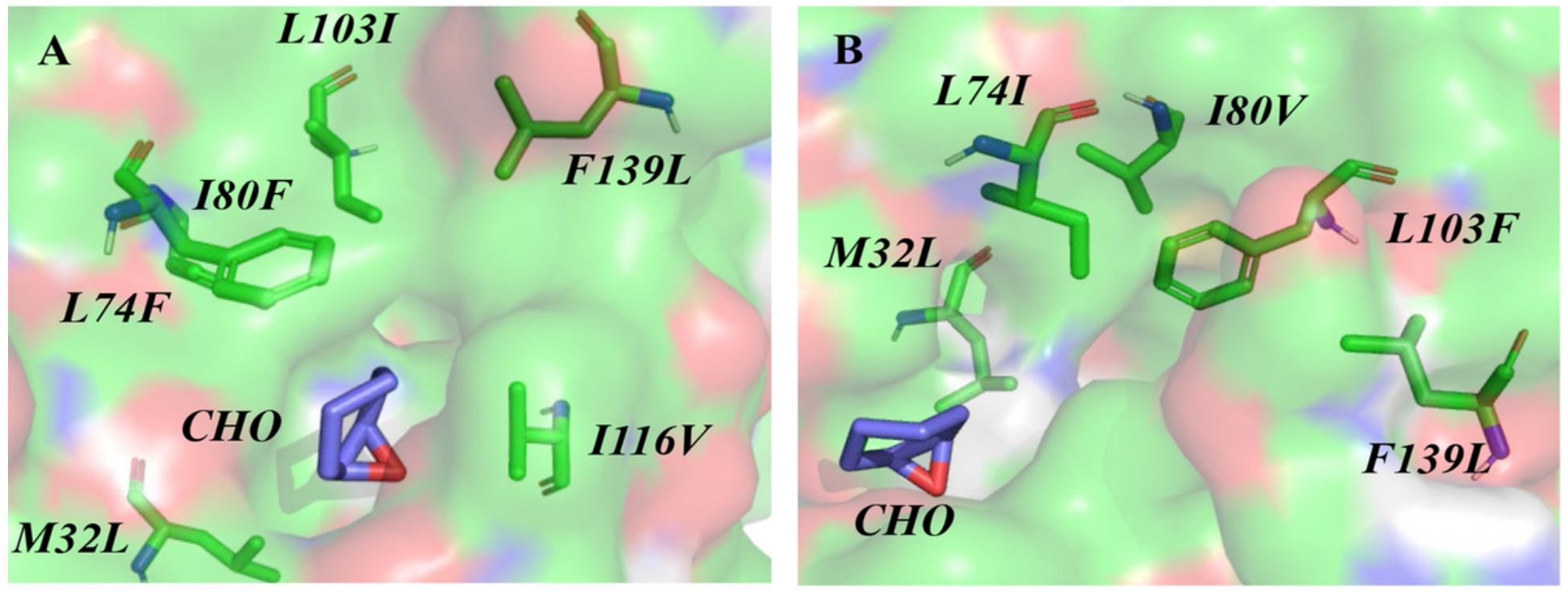

Figure 4

Molecular docking the substrate $\mathrm{CHO}$ with LEH mutants. A: Docking of substrate $\mathrm{CHO}$ and $\mathrm{BE} 3$; $\mathrm{B}$ : Docking of substrate $\mathrm{CHO}$ and $\mathrm{BG} 5$;

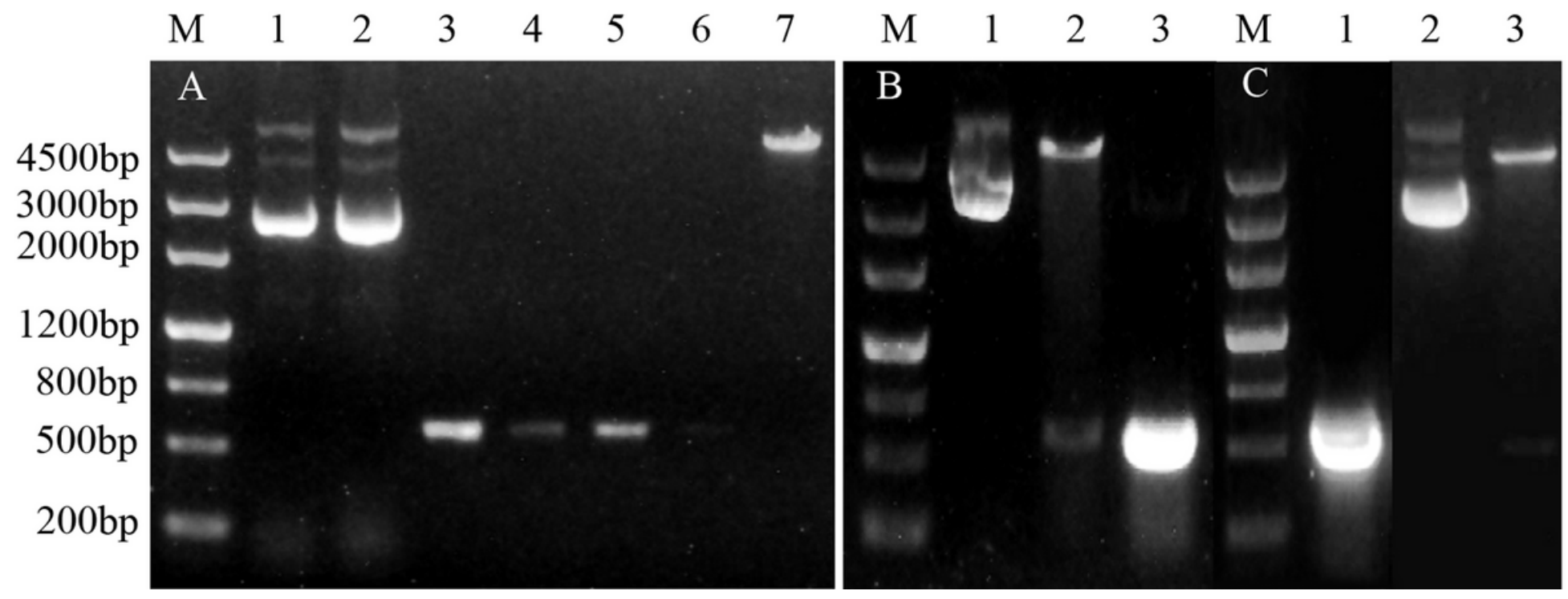

\section{Figure 5}

Target gene and transformant electrophoresis of pHY-p43-LEH system. A: M: Marker, 1: pBAD-BE3, 2: pBAD-BG5, 3-4: pBAD-BE3 PCR amplification and restriction enzyme digestion, 5-6: pBAD-BG5 PCR amplification and restriction enzyme digestion, 7: pHY-p43 restriction enzyme digestion; $\mathrm{B}: 1$ : recombinant plasmid pHY-p43-BE3, 2: PCR amplification pHY-p43-BE3, 3: restriction enzyme digestion of pHY-p43-BE3; C: 1: recombinant plasmid pHY-p43-BG5, 2: PCR amplification pHY-p43-BG5, 3: restriction enzyme digestion of pHY-p43-BG5. 


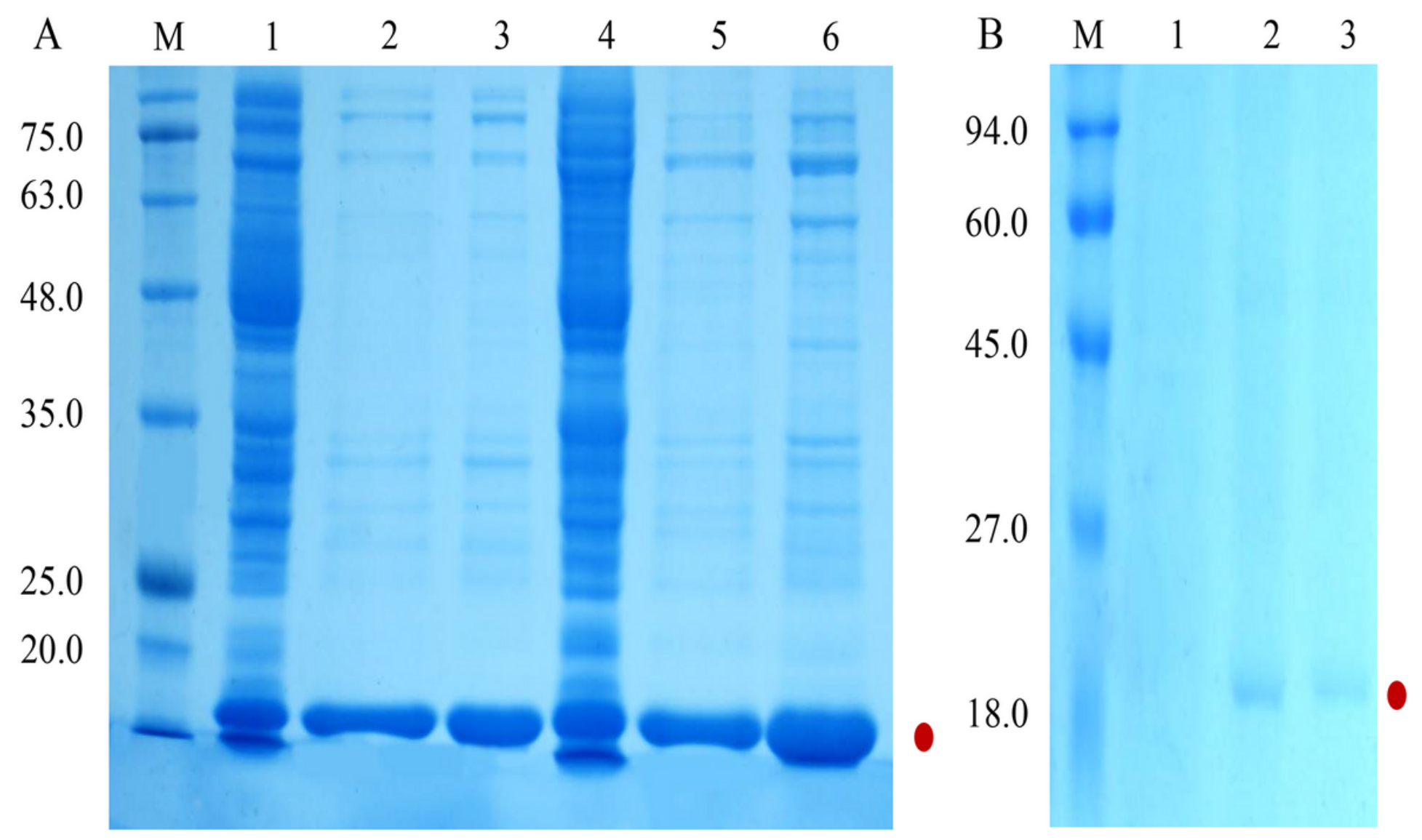

Figure 6

pHY-p43-LEH heterologous expression in E.coli Top10 and B.subtilis WB800. A: M: Marker, 1: crude enzyme of pHY-p43-BE3, 2: purification enzyme of pHY-p43-BE3, 3: desalination enzyme of pHY-p43-BE3, 4: crude enzyme of pHY-p43-BG5, 5: purification enzyme of pHY-p43-BG5, D6: desalination enzyme of pHY-p43-BG5. B: M: Marker, 1-3: purification enzyme of pHY-p43-BE3 

A $-\square-\operatorname{diol}(\mathrm{S}, \mathrm{S})$ concentration (mmol/L)
A $\quad-$ enzyme activity $(\mathrm{U} / \mathrm{mg} / \mathrm{min}$
$=-$ ee $(\%)$
$-=-$ conversion $(\%)$

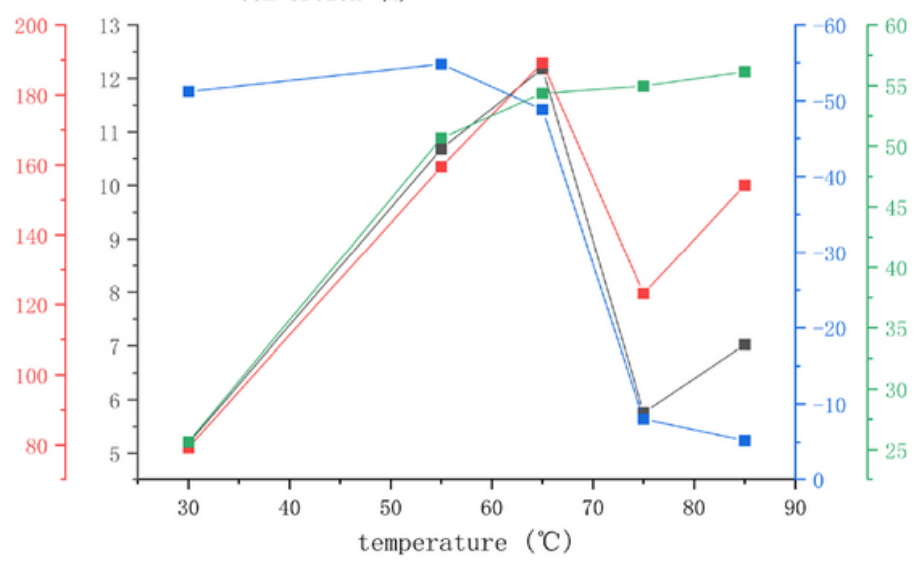

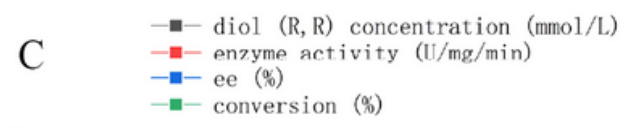

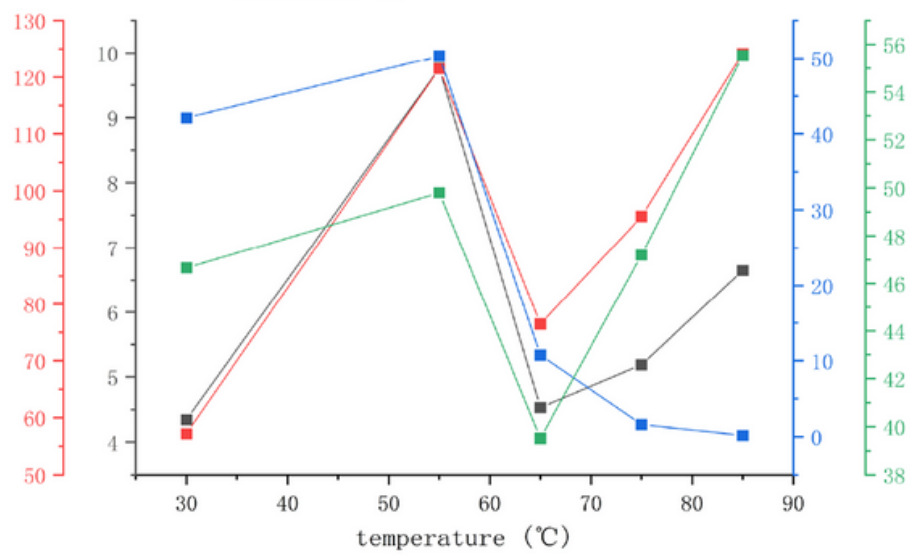

$$
\begin{aligned}
& \text { B }-\square-\operatorname{diol}(\mathrm{S}, \mathrm{S}) \text { concentration (mmol/L) } \\
& \text { B } \quad-\text { enzyme activity (U/mg/min) } \\
& \text { - }- \text { ee (\%) }
\end{aligned}
$$

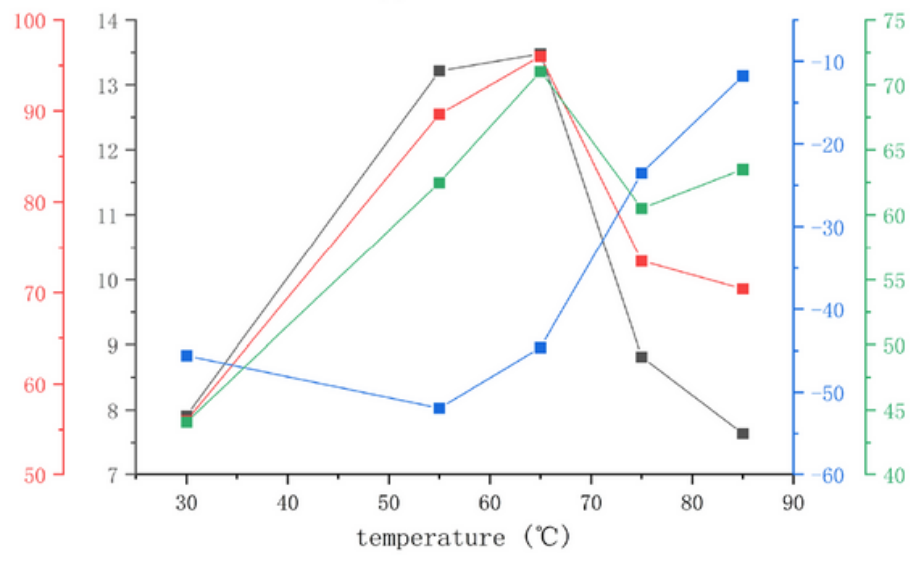

D $-\operatorname{diol}(\mathrm{R}, \mathrm{R})$ concentration (mmol/L)

D $\quad-$ - enzyme activity $(\mathrm{I} / \mathrm{mg} / \mathrm{min})$ $-m-$ ee $(\%)$

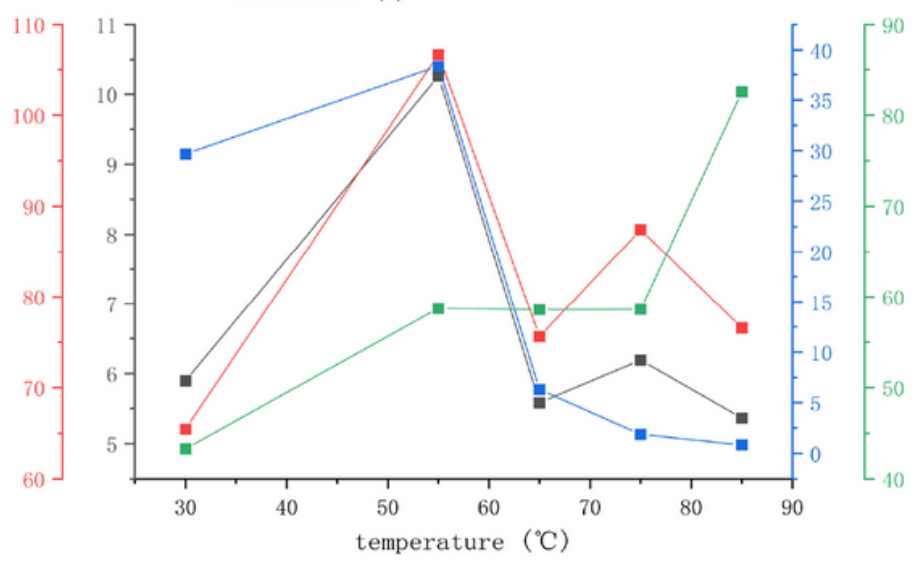

\section{Figure 7}

Temperature of enzymatic characteristics of mutants. A: p43-BE3; B: pBAD-BE3; C: p43-BG5; D: pBAD-BG5 


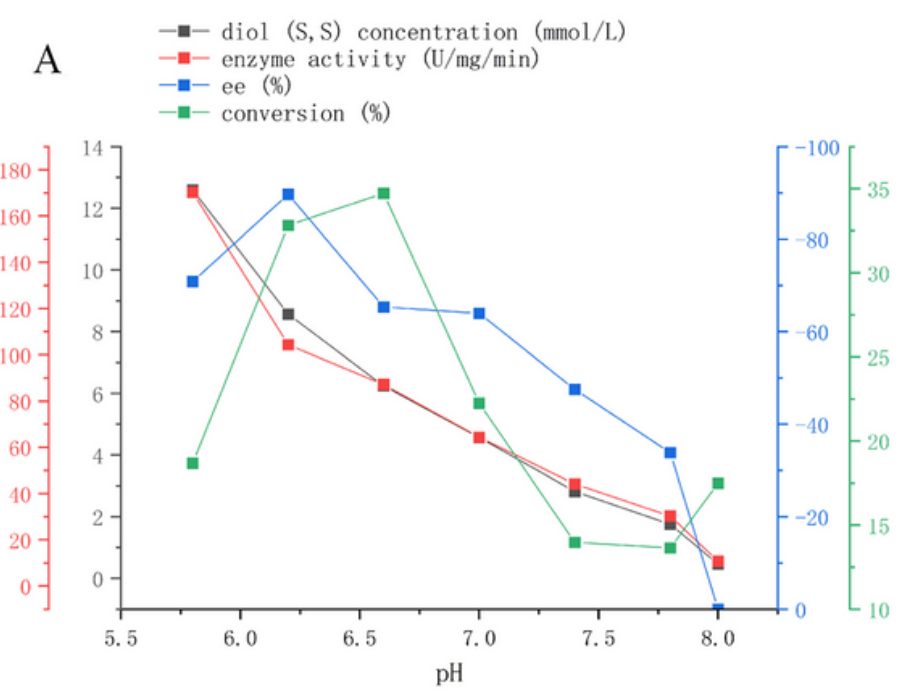
B $\quad-\quad-$ diol $(\mathrm{S}, \mathrm{S})$ concentration $(\mathrm{mmol} / \mathrm{L})$
- - ee $(\%)$

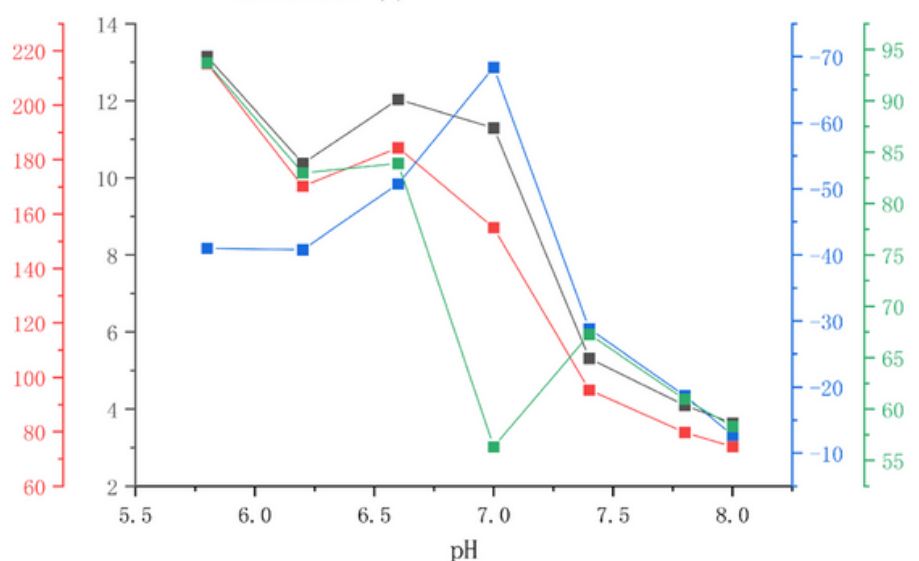

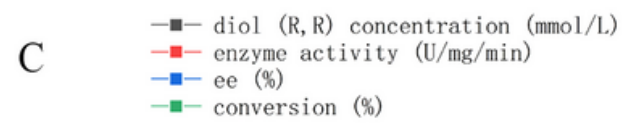

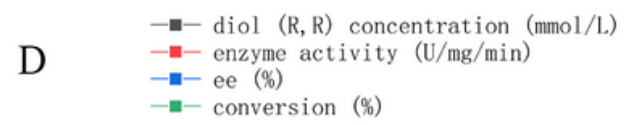
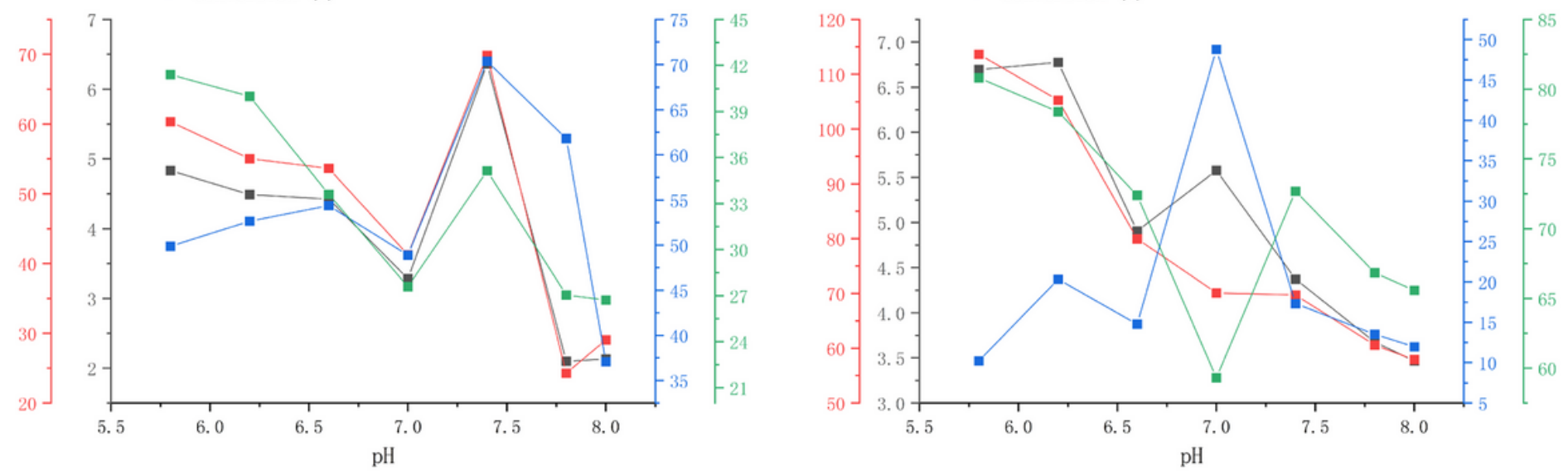

\section{Figure 8}

pH of enzymatic characteristics of mutants. A: p43-BE3; B: pBAD-BE3; C: p43-BG5; D: pBAD-BG5 

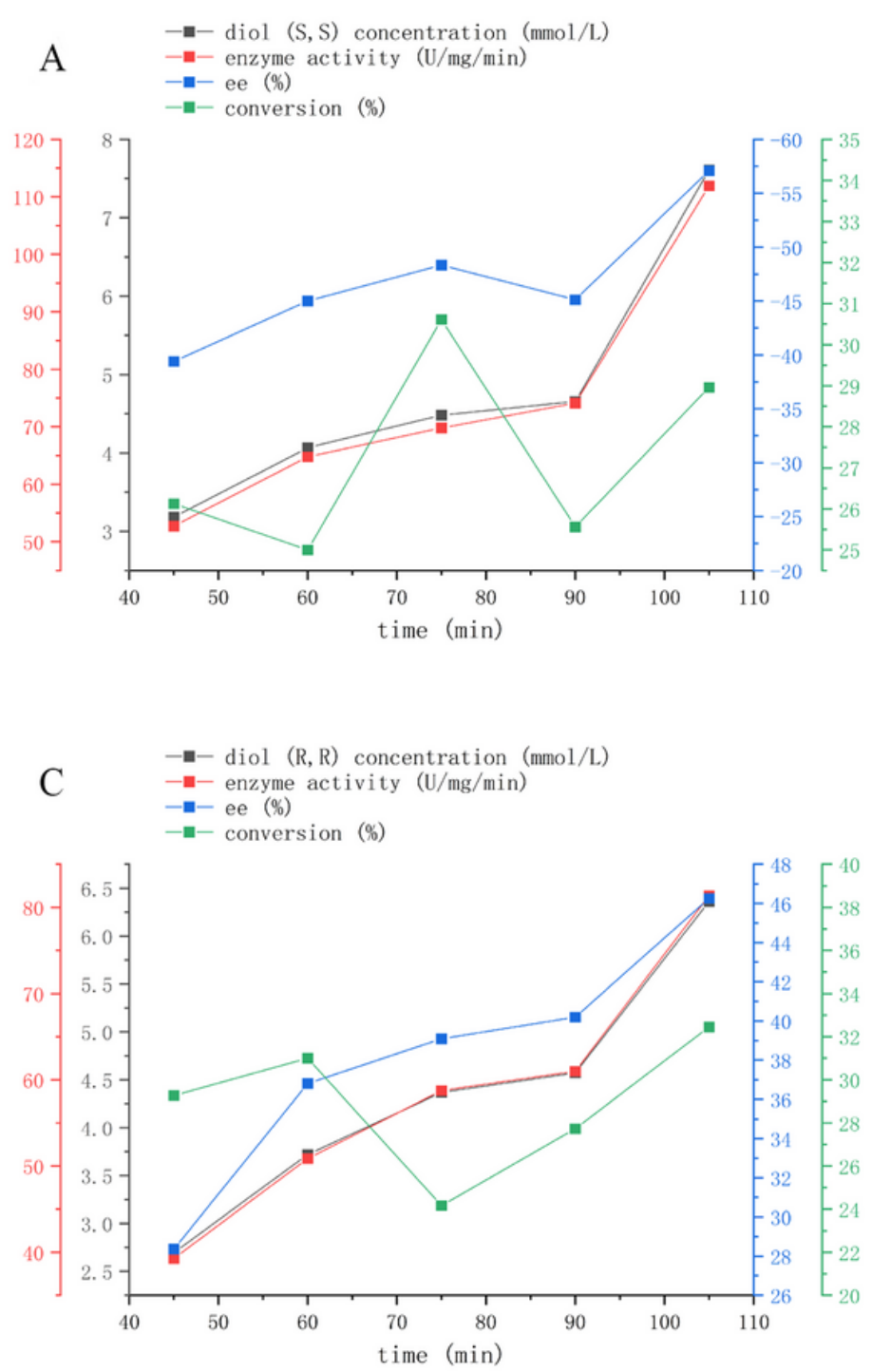
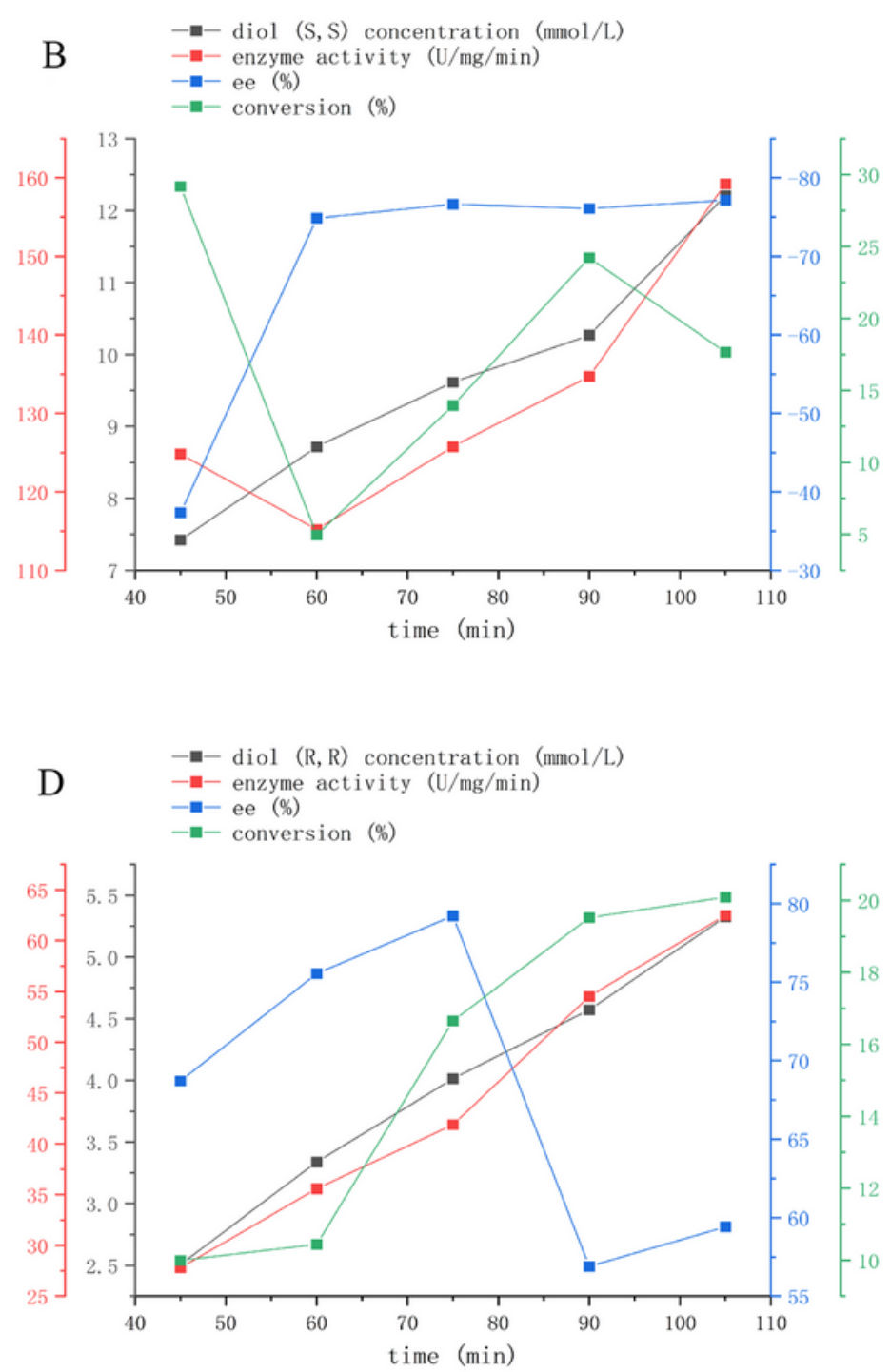

\section{Figure 9}

Reaction time of enzymatic characteristics of mutants. A: p43-BE3; B: pBAD-BE3; C: p43-BG5; D: pBADBG5 
- - diol concentration (mmol/L)

- - enzyme activity (U/mg/min)

- - ee $(\%)$

$-\square-$ conversion $(\%)$

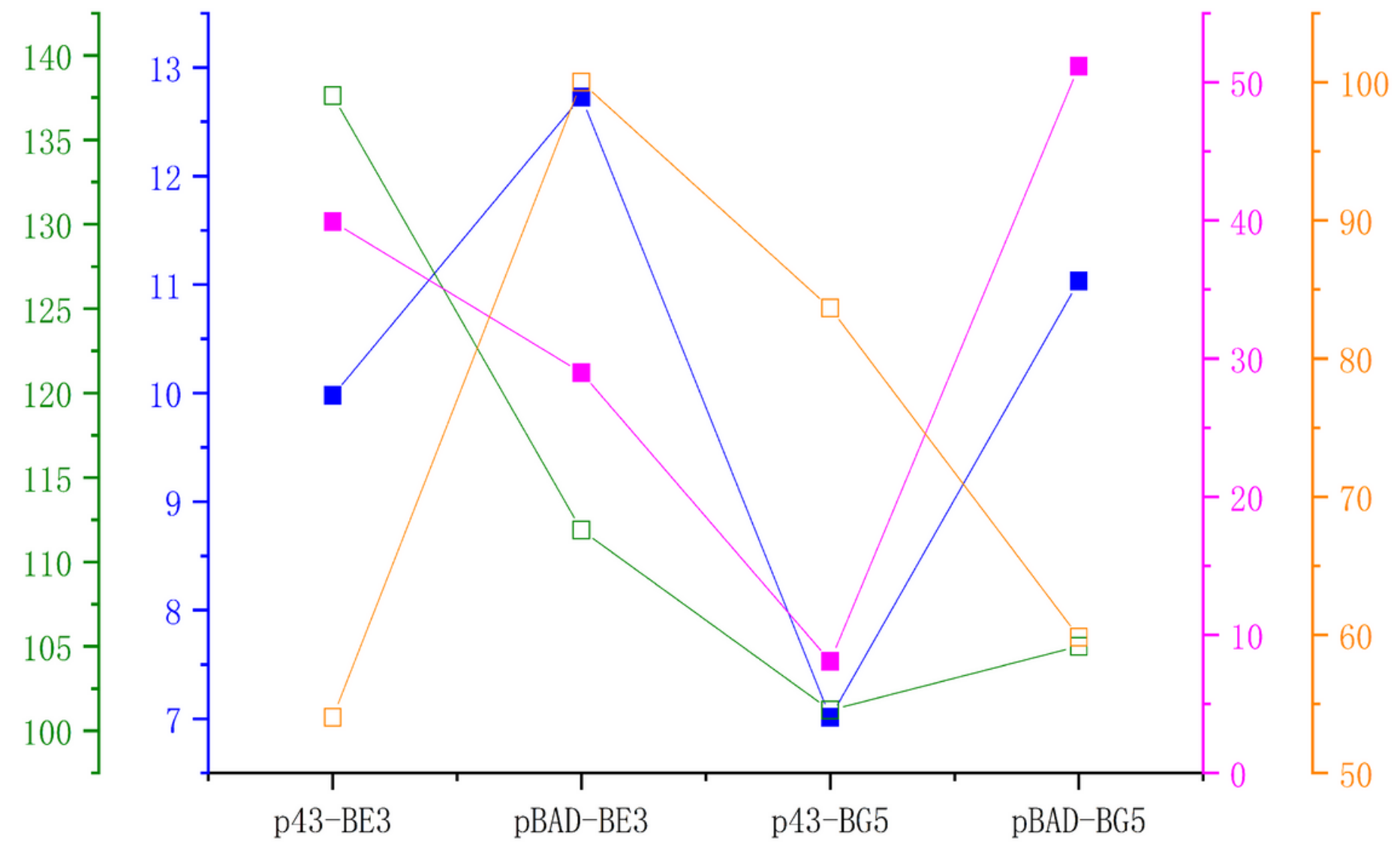

Figure 10

Enzyme-catalyzed reaction in single-factor optimal conditions 